\title{
Pengetahuan Ibu Hamil Tentang Akupresur di Puskesmas Margodadi
}

\author{
Neni Setianingsih ${ }^{1}$, Widayati $^{2}$ \\ ${ }^{1,2}$ Kebidanan Program Sarjana Fakultas Kesehatan, Universitas Ngudi Waluyo \\ Email : nenisetia50@gmail.com,widayati.alif@gmail.com
}

\begin{abstract}
ABSTRAK
Perubahan selama kehamilan seringkali menyebabkan ketidaknyaman pada ibu hamil seperti mual muntah, migrain, sulit tidur dan nyeri punggung. Akupresur pada kehamilan merupakan terapi non farmakologi yang digunakan untuk mengatasi ketidaknyaman ibu hamil. Penelitian deskriptif kuantitatif, metode pendekatan cross sectional. Populasi dari penelitin ini adalah seluruh ibu hamil di Puskesmas Margodadi bulan November 2020 dengan jumlah 63 ibu hamil. Teknik pengambilan sampel adalah total sampling dan analisis yang digunakan analisis univariat Mendeskripsikan pengetahuan ibu hamil tentang akupresur, pengertian akupresur, manfaat akupresur, kontraindikasi akupresur, cara melakukan akupresur, dan titik-titik akupresur yang dapat dilakukan pada kehamilan. sebagian besar responden berpengetahuan kurang bepengetahuan kurang tentang pengetahuan akupresur $51(81,0 \%)$, berpengetahuan kurang tentang pengertian 51 responden $(51,0 \%)$, berpengetahuan kurang tentang manfaat 49 responden $(77,8 \%)$, berpengetahuan kurang tentang kontraindikasi 52 (82,5\%), berpengetahuan kurang tentang cara melakukan $40(63,5 \%)$, dan bepengetahuan kurang tentang titik-titik akupresur yang dapat dilakukan pada kehamilan 35 (55,6\%). Sebagian besar ibu hamil dalam pengetahuan kurang tentang pengetahuan akupresur 51 (81,0\%). Diharapkan ibu hamil mencari informasi tentang akupresur pada kehamilan dari Bidan. Dan harapan untuk Bidan, hendaknya dapat mengikuti seminar dan pelatihan tentang akupresur pada kehamilan.
\end{abstract}

\section{Kata Kunci : Pengetahuan, ibu hamil, Akupresur}

\begin{abstract}
Knowledge of Pregnant Women About Acupressure at Margodadi Health Center Changes during pregnancy often cause discomfort in pregnant women, discomfort that is often experienced in the form of nausea, vomiting, migraines, difficulty sleeping and back pain. Acupressure in pregnancy is a non-pharmacological therapy that can be used to treat the discomfort of pregnant women. Descriptive quantitative research. The method used cross sectional approach. The population of this study were all pregnant women at Margodadi Health Center in November 2020 with total of 63 mothers. The sampling technique was total sampling and used Univariate analysis. Describe the knowledge of pregnant women about acupressure, the definition of acupressure, the benefits of acupressure, acupressure contraindications, how to do acupressure, and acupressure points that can be used in pregnancy. The results of the univariate analysis, most of the respondents had less knowledge about the understanding of 51 respondents (51.0\%), less knowledgeable about the benefits of 49 respondents (77.8\%), less knowledgeable about contraindications 52 (82.5\%), less knowledgeable about how to do 40 (63.5\%), less knowledge about acupressure points that can be done in pregnancy

Pengetahuan Ibu Hamil... Neni Setianingsih, Widayati Journal of Holistics and Health Sciences Vol. 3, No. 2 September 2021
\end{abstract}


35 (55.6\%), and less knowledge about acupressure knowledge 51 (81.0\%). Most of the pregnant women lacked knowledge of acupressure knowledge 51 (81.0\%). Most of the pregnant women lacked knowledge of acupressure knowledge 51 (81.0\%). It is expected that pregnant women seek information about acupressure in pregnancy from the midwife. And hope for midwives, should be able to attend seminars and training on acupressure in pregnancy.

\section{Keywords: Knowledge, Pregnant Women, Acupressure}

\section{PENDAHULUAN}

Kehamilan merupakan suatu keadaan di dalam rahim seorang wanita yang terdapat hasil konsepsi (pertemuan ovum dan spermatozoa). Kehamilan dalah suatu proses yang alamiah dan fisiologis semua wanita (Yanti, 2017). Sedangkan menurut Federasi Obstetri Ginekologi Internasional, kehamilan diartikan sebagai fertilisasi atau penyatuan dari spermatozoa dan ovum kemudian dilanjutkan dengan nidasi atau implantasi. Bila dihitung dari saat fertilisasi hingga lahirnya bayi, kehamilan normal akan berlangsung dalam waktu 40 minggu atau 10 bulan atau 9 bulan menurut kalender internasional (Prawirohardjo, 2014). Selama proses kehamilan terdapat beberapa perubahan yang dapat terjadi dan dialami oleh ibu hamil. Perubahan ini berupa perubahan sistem tubuh ibu yang membutuhkan adaptasi baik fisik ataupun psikologis. Perubahan-perubahan tersebut sering kali menimbulkan ketidaknyamanan pada ibu hamil. Ketidaknyamanan yang dirasakan oleh ibu berbeda-beda tiap trimesternya. Perubahan yang sering dialami ibu selama kehamilan adalah mual muntah, pusing, nyeri punggung, flek hitam pada wajah, kram pada kaki, kenaikan berat badan, insomnia, dan sering berkemih (Irianti, 2013).

Banyak cara yang dilakukan oleh ibu hamil saat menghadapi ketidaknyamanan selama kehamilan, baik dengan cara terapi farmakologi maupun non farmakologi. Farmakologi adalah pengobatan yang dilakukan dengan mengkonsumsi obat-obatan. Sedangakan non farmakologi merupakan jenis terapi komplementer yang dapat digunakan sebagai intervensi untuk mengatasi keluhan-keluhan yang dirasakan ibu hamil, diantaranya : akupresur, akupuntur, relaksasi, dan terapi (Meiri dan Kibas, 2018). Akupresur merupakan perkembangan terapi pijat yang berlangsung seiring dengan perkembangan ilmu akupuntur, karena teknik pijat akupresur adalah turunan dari ilmu akupuntur. Teknik dalam terapi ini menggunakan jari tangan sebagai pengganti jarum tetapi akupresur dilakukan pada titik-titik yang sama seperti yang digunakan pada terapi akupuntur (Hartono, 2012). Pada kehamilan akupresur sering digunakan sebagai alternatif pengobatan non farmakologi untuk mengatasi ketidaknyamanan ibu selama kehamilan karena pengaruh perubahan-perubahan fisiologis. Perubahan fisiologis dalam kehamilan yang dapat menggunakan akupresure sebagai alternatif diantaranya seperti pusing, meningkatkan kualitas tidur, mual muntah, mengurangi kecemasan, dan nyeri punggung. Penelitian yang dilakukan Sukeksi tahun 2018, didapatkan hasil bahwa akupresure dapat mengurangi nyeri punggung 
pada ibu hamil. Menurut Neri et al. (2015) menyatakan bahwa melakukan akupresur pada titik HT 7 dapat meningkatkan kualitas tidur dan mengurangi perasaan cemas pada ibu hamil trimester III. Penelitian lain menyebutkan bahwa melakukan akupresur pada titik BL32 selama 20 menit dapat mengurangi tingkat kecemasan pada ibu menjelang persalinan (Akbarzadeh, Masoudi, Zare, \& Vaziri, 2015).

Rumusan permasalahannya yaitu bagaimanakan pengetahuan Ibu Hamil tentang Akupresur di Puskesmas Margodadi Kecamatan Tumijajar Kabupaten Tulang Bawang Barat Provinsi Lampung. Sedangkan tujuan penelitiannya yaitu mendeskripsikan pengetahuan ibu hamil tentang akupresur di Puskesmas Margodadi Kecamatan Tumijajar Kabupaten Tulang Bawang Barat Provinsi Lampung

\section{Hasil}

Hasil penelitian yang disajikan adalah data kuantitatif dengan bentuk analisa univariat yang

\section{METODE}

Desain penelitian yang digunakan adalah penelitian deskriptif kuantitatif, dengan metode pendekatan cross sectional. Populasi dalam penelitian ini adalah seluruh ibu hamil di Puskesmas Margodadi pada bulan November 2020. Pengambilan sampel dilakukan dengan teknik total sampling dengan jumlah sampel 63 responden. Instrumen yang digunakan dalam penelitian ini adalah Kuisoner dengan 17 soal pernyataan. Analisa yang digunakan dalam penelitian ini adalah analisa univariat untuk menganalisa setiap variabel dari hasil penelitian dan disajikan dalam bentuk distribusi frekuensi. Analisa univariat dilakukan dengan menggunakan SPSS Versi 20.

\section{HASIL DAN PEMBAHASAN}

bertujuan untuk mengetahui distribusi frekuensi dari masing-masing variabel yang diteliti

Tabel 1 Distribusi Frekuensi Pengetahuan Ibu Hamil Tentang Akupresur

\begin{tabular}{lll}
\hline pengetahuan & frekuensi & presentasi \\
\hline Baik & 0 & 0 \\
Cukup & 12 & 19 \\
Kurang & 51 & 81 \\
\hline jumlah & $\mathbf{6 3}$ & $\mathbf{1 0 0}$ \\
\hline
\end{tabular}

Dari tabel 1 sebagian besar responden dalam pengetahuan kurang sebanyak 51 responden $(81,0 \%)$.

Tabel 2 Distribusi Frekuensi Pengetahuan Ibu Hamil Tentang Pengertian Akupresur

\begin{tabular}{ccc}
\hline pengetahuan & frekuensi & presentasi \\
\hline Baik & 2 & 3,2 \\
Cukup & 10 & 15,9 \\
Kurang & 51 & 81 \\
\hline jumlah & $\mathbf{6 3}$ & $\mathbf{1 0 0}$ \\
\hline
\end{tabular}


Dari tabel 2 sebagian besar responden dalam pengetahuan kurang sebanyak 51 responden $(81,0 \%)$.

Tabel 3 Distribusi Frekuensi Pengetahuan Ibu Hamil Tentang Manfaat Akupresur

\begin{tabular}{ccc}
\hline pengetahuan & frekuensi & presentasi \\
\hline Baik & 0 & 3,2 \\
Cukup & 14 & 22,2 \\
Kurang & 49 & 78,2 \\
\hline jumlah & $\mathbf{6 3}$ & $\mathbf{1 0 0}$ \\
\hline
\end{tabular}

Berdasarkan tabel 3 menunjukkan bahwa pengetahuan responden tertang manfaat akupresur berpengetahun kurang sejumlah 49 responden $(78,2 \%)$.

Tabel 4 Distribusi Frekuensi Pengetahuan Ibu Hamil Tentang Kontraindikasi Akupresur

\begin{tabular}{ccc}
\hline pengetahuan & frekuensi & presentasi \\
\hline Baik & 1 & 1,6 \\
Cukup & 10 & 15,9 \\
Kurang & 52 & 82,5 \\
\hline jumlah & $\mathbf{6 3}$ & $\mathbf{1 0 0}$ \\
\hline
\end{tabular}

Tabel 4 menunjukkan bahwa pengetahuan responden tentang kontraindikasi termasuk dalam berpengathuan kurang sebanyak 52 responden $(82,5 \%)$.

Tabel 5 Distribusi Frekuensi Pengetahuan Ibu Hamil Tentang Cara Melakukan Akupresur

\begin{tabular}{lll}
\hline pengetahuan & frekuensi & presentasi \\
\hline Baik & 5 & 7,9 \\
Cukup & 18 & 28,6 \\
Kurang & 40 & 63,5 \\
\hline Jumlah & $\mathbf{6 3}$ & $\mathbf{1 0 0}$ \\
\hline
\end{tabular}

Tabel 5 menunjukkan bahwa

berpengathuan kurang sebanyak 40 pengetahuan responden tentang cara responden $(63,5 \%)$.

melakukan akupresur termasuk dalam

Tabel 6 Distribusi Frekuensi Pengetahuan Ibu Hamil Tentang Titik-Titik Akupresur Yang Dapat Dilakukan Pada Kehamilan

\begin{tabular}{lll}
\hline pengetahuan & frekuensi & presentasi \\
\hline Baik & 4 & 6,3 \\
Cukup & 24 & 38,1 \\
Kurang & 35 & 55,6 \\
\hline Jumlah & $\mathbf{6 3}$ & $\mathbf{1 0 0}$ \\
\hline
\end{tabular}

Dari tabel 6 sebagian besar responden dalam pengetahuan kurang sebanyak 35 responden $(55,6 \%)$.

\section{PEMBAHASAN}

1. Pengetahuan ibu tentang akupresur Hasil penelitian pengetahuan ibu hamil tentang akupresur sebagian besar dalam pengetahuan kurang sebanyak 51 
responden $(81,0 \%)$, pengetahuan cukup sebanyak 10 responden $(15,9 \%)$ dan pengetahuan baik sebanyak 2 responden $(3,2 \%)$. Ibu hamil kurang mengetahui tentang akupresur baik dari pengertian, manfaat, kontraindikasi, cara melakukan dan titik-titik akupresur yang dapat dilakukan pada kehamilan. Dari keseluruhan responden hanya 2 responden $(3,2 \%)$ yang pernah mendengar informasi tentang akupresur dengan pengetahuan yang cukup. Faktor yang menjadikan ibu hamil memiliki pengetahuan kurang karena akupresur masih asing dalam kalangan masyarakat, serta kurangnya informasi tentang akupresur untuk kehamilan. Ibu hamil yang berada diwilayah kerja Puskesmas Margodadi memiliki keterbatasan dalam mencari informasi tentang akupresur pada kehamilan. Meskipun saat ini era globalisasi berkembang pesat,akan tetapi sebagian besar ibu hamil belum mampu mengoperasikan gadget dengan baik guna memproleh informasi tentang akupresur pada kehamilan.selain itu, tidak sedikit dari mereka belum memiliki handphone yang mampu mengakses informasi tentang akupresur pada kehamilan. Informasi tentang seputar kehamilan mereka dapatkan melalui tenga kesehatan yaitu bidan saat melakukan posyandu ibu hamil setiap bulanya ataupun dari bidan desa yang berada diwilayah mereka saat ibu hamil melakukan kunjungan ANC ke tempat bidan desa. Akupresur pada kehamilan juga masih tergolong baru dalam pengobatan non farmakologi untuk mengurangi ketidaknyamanan kehamilan. Bahkan, para petugas kesehatan terutama bidan yang bertugas di Puskesmas masih merasa asing dengan akupresur pada kehamilan. Hal ini tentu saja menjadikan pengetahuan ibu hamil kurang, terlebih pengetahuan seputar kehamilan didapatkan oleh ibu hamil hanya dari tenga kesehatan/bidan saja. Selain itu faktor pendidikan juga yang menjadikan ibu masih kurang dalam pengetahuan. Menurut Carter (2011) semakin tinggi tingkat pendidikan seseorang maka semakin mudah juga orang tersebut menerima informasi sehingga semakin banyak pula pengetahuan dan pengalaman yang ia miliki. Pada penelitian ini sebagian besar responden berpendidikan dasar sebanyak 37 responden $(58,7 \%)$ dan semua responden dalam pengetahuan kurang. Selain faktor pendidikan, faktor pekerjaan dan lingkungan juga sangat berpengaruh dalam pengetahuan ibu. Faktor lingkungan dan pekerjaan ibu hamil juga berperan dalam sumber pengetahuan ibu hamil tentang akupresur pada kehamilan. Ibu hamil dalam penelitian ini sebagian besar bekerja sebagai IRT sebanyak 49 responden $(77,8 \%)$ yang menjadikan pengetahuan ibu tidak bertambah karena hanya terfokus pada pekerjaan rumah. Hal ini dapat terjadi karena ibu hamil tidak bertemu dengan orang-orang yang memiliki pengetahuan baik, otomatis ibu hamil akan memiliki pengetahuan baik karna ibu hamil berada dalam lingkup orang berpengetahuan baik. Menurut 
Budiman dan Riyanto (2013) lingkungan pekerjaan dapat menjadikan seseorang mendapatkan pengalaman dan pengetahuan, baik secara langsung maupun tidak langsung. Teori tersebut sudah sesuai dengan penelitian ini, karna sebagian besar responden bekerja sebagai IRT sebanyak 49 responden $(77,8 \%)$ dengan ibu yang berpengetahuan kurang 48 responden $(65,1 \%)$, berpengetahuan cukup 1 responden $(1,6 \%)$. Menurut penelitian yang dilakukan Pangesti (2012), pekerjaan seseorang dapat berpengaruh terhadap pengetahuan dan pengalaman seseorang, karena ketika pekerjaan itu lebih sering menggunakan otak daripada menggunakan otot. Sehingga kinerja dan kemampuan otak seseorang dalam mengingat akan bertambah ataupun meningkat apabila sering digunakan. Hal ini berbanding lurus dengan pekerjaan seseorang yang menggunakan otot. Dan faktor lingkungan mempengaruhi proses masuknya pengetahuan kedalam individu karena adanya interaksi timbal balik ataupun tidak yang akan direspons sebagai pengetahuan oleh individu. Lingkungan yang baik akan pengetahuan yang didapatkan akan baik tapi jika lingkungan kurang baik maka pengetahuan yang didapat juga akan kurang baik. Jika seseorang berada di sekitar orang yang berpendidikan maka pengetahuan yang dimiliki seseorang akan berbeda dengan orang yang berada di sekitar orang pengangguran dan tidak berpendidikan.
2. Pengetahuan ibu hamil tentang pengertian akupresur di Puskesmas Margodadi

Hasil penelitian pengetahuan ibu hamil tentang pengertian akupresur sebagian besar dalam pengetahuan kurang sebanyak 51 responden $(81,0 \%)$. Ibu hamil kurang mengerti tentang pengertian akupresur, seperti ibu hamil mengerti bahwa akupresur merupakan pengembangan dari ilmu akupuntur sehingga prinsipnya sama. Yang membedakan dengan terapi akupuntur adalah terapi akupresur menggunakan jari tangan dan teknik akupuntur menggunakan jarum. Menurut Kholid dan Notoadmodjo (2012), pengetahuan memiliki beberapa tingkatan yang salah satunya adalah Tahu (Know) yang diartikan sebagai mengingat kembali (recall) suatu materi yang telah dipelajari dan diterima dari sebelumnya. Sebagian besar responden belum sesuai dengan teori tersebut, karena responden kurang mengerti tentang pengertian akupresur. Sebagian besar responden dalam penelitian ini berpendidikan terakir SMP sebanyak 24 orang $(38,1 \%)$. Sebagian besar responden berpendidikan SMP memiliki pengetahuan kurang sebanyak 24 responden $(38,1 \%)$, dan tidak satupun responden dalam pengetahuan baik dan cukup. Pada pernyataan teknik akupresur dan akupuntur menggunakan jarum, sebagian responden memberikan jawaban yang salah sebanyak 46 responden $(73,0 \%)$ dan yang menjawab dengan benar sebanyak 17 responden $(27,0 \%)$. Hal ini sesuai dengan penelitian 
$\begin{array}{llr}\text { Hartatik } & \text { (2012) } & \text { tingkat } \\ \text { pendidikan } & \text { seseorang } & \text { turut }\end{array}$ menentukan dalam pemahaman dan penyerapan seseorang tentang pengetahuan.

3. Pengetahuan ibu hamil tentang manfaat akupresur di Puskesmas Margodadi

Hasil

penelitian

pengetahuan ibu hamil tentang manfaat akupresur sebagian besar dalam pengetahuan kurang sebanyak 49 responden $(77,8 \%)$. Ibu hamil kurang mengetahui manfaat dari akupresur seperti menghilangkan nyeri dan gejalagejala pada berbagai penyakit seperti Low back pain (LBP) dan menurunkan heart rate pada pasien stroke. Akupresur juga dapat digunakan untuk mengatasi nyeri pada saat menstruasi (disminore) dan distress menstrual (Setyowati, 2018). Menurut Budiman dan Riyanto (2013) terdapat beberapa faktor yang mempengaruhi pengetahuan salah satunya informasi atau media massa yang diartiakan sebagai suatu teknik untuk mengumpulkan, menyiapkan, menyimpan, memanipulasi, mengumumkan, menganalisis dan menyebarkan informasi dengan tujuan tertentu. Informasi mempengaruhi pengetahuan seseorang jika sering mendapatkan informasi tentang suatu pembelajaran maka akan menambah pengetahuan dan wawasannya, sedangkan seseorang yang tidak sering menerima informasi tidak akan menambah pengetahuan dan wawasannya. Sebagian besar responden dalam kriteria kurang dan belum sesuai dengan teori tersebut. Hal ini dikarenakan minimnya informasi tentang akupresur untuk dapat diakses oleh ibu hamil sehingga ibu hamil kurang mendapatkan informasi untuk menambah wawasanya. Dari total 63 responden hanya 2 responden $(3,2 \%)$ yang pernah mendengar informasi tentang akupresur dan dalam kriteria cukup. Pada pernyataan akupresur tidak bermanfaat untuk penyembuhan penyakit Low back pain (nyeri punggung) sebagian besar responden memberikan jawaban yang salah sebanyak 46 respon (70,3\%), akupresur bermanfaat untuk meningkatkan daya tahan tubuh sebagian besar responden memberikan jawaban yang salah sebanyak 46 responden $(73,0 \%)$, dan akupresur dapat digunakan untuk mengatasi nyeri pada saat menstruasi (disminore) atau distress menstrual sebagian besar responden memberikan jawabany yang salah sebanyak 39 responden (61,9\%). Dapat disimpulkan bahwa sebagian besar responden memberikan jawaban yang salah pada setiap pernyataan manfaat akupresur. Hal ini dikarenakan sebagian besar responden belum pernah mendengar informasi tentang akupresur. Menurut penelitian Kundaryanti dan Rukmini (2016) ada hubungan yang signifikan antara sumber informasi dengan pengetahuan seseorang. Hal ini sejalan dengan penelitian yang dilakukan Yuli Catur Putri (2012), sumber informasi merupakan suatu perantara dalam menyampaikan informasi, merangsang pikiran dan kemampuan, informasi yang diperoleh dalam menyampaikan 
informasi yang diperoleh dari berbagai sumber akan mempengaruhi tingkat pengetahuan seseorang. jika seseorang sering memperoleh informasi, maka orang tersebut mempunyai pengetahuan yang lebih luas. Semakin sering seseorang memperoleh informasi, semakin banyak pula pengetahuan yg dimiliki.

4. Pengetahuan ibu hamil tentang kontraindikasi akupresur di Puskesmas Margodadi

Hasil penelitian ibu hamil tentang kontraindikasi akupresur sebagian besar dalam pengetahuan kurang sebanyak 52 $(82,5 \%)$, pengetahuan cukup 10 responden $(15,9 \%)$ dan pengetahuan baik 1 responden $(1,6 \%)$. Ibu hamil kurang mengetahui tentang kontraindikasi akupresur. Akupresur sebaiknya tidak dilakukan pada daerah yang terasa nyeri, suhu badan meningkat, influenza berat, nyeri rematik, tidak sadar, daerah kemaluan, serta tidak dilakukan pada kamar yang lembab (Sunetra, 2004). Pemanfaatan akupresur sebaiknya tidak dilakukan pada pasien dalam keadaan terlalu lapar, kenyang, capek, emosi, setelah donor darah, serta setelah berolahraga (Kemenkes, 2011). Pada kehamilan titik akupresur yang harus di hindari yaitu titik GB21, LI4, SP6 dan ST36 karena titik-titik tersebut dapat menstimulasi kontraksi uterus. Hindari titik-titik yang dapat memberi pengaruh buruk pada pertumbuhan, perkembangan dan kesehatan janin pada usia gestasi tertentu misalnya pada titik abdomen dari usia 24 minggu sampai 32 minggu (Tiran, 2009). Menurut penelitian yang dilakukan Pangesti (2012), pada usia produktif merupakan usia yang paling memiliki peran dan aktivitas cukup padat serta memiliki kemampuan kognitif yang baik. Sehingga pada usia ini sangat memiliki pengaruh terhadap tingkat pengetahuan seseorang. Pada pernyataan orang dalam keadaan lapar dapat dilakukan pijat akupresur sebagian besar responden memberikan jawaban yang salah sebanyak 32 responden $(50,8 \%)$ yang benar 31 responden $(49,2 \%)$, pada kehamilan titik LI4 dapat dilakukan akupresur sebagian besar responden memberikan jawaban yang salah sebanyak 45 responden $(71,4 \%)$ yang benar 18 responden $(28,6 \%)$, titik ST36 dapat dilakukan pijat akupresur saat kehamilan sebagian besar responden memberikan jawaban yang salah sebanyak 41 responden $(65,1 \%)$ yang benar 22 responden $\quad(34,9 \%)$.dapat disimpulkan bahwa sebagian besar responden memberikan jawaban yang salah pada setiap pernyataan. Hal ini belum sesuai dengan penelitian Astuti (2012) terdapat hubungan umur dengan pengetahuan seseorang dengan rentang umur 20-45 merupakan usia matang seseorang dimana pada umur tersebut akan memiliki daya tangkap dan daya pikir yang baik sehingga pengetahuan orang tersebut juga baik. Hal ini diikarenakan sebagian besar responden berumur 21-35 tahun sebanyak 50 responden $(79,4 \%)$, dan sebagian besar responden berpengetahuan kurang sebanyak 48 responden $(76,2 \%)$ dan 
berpengetahuan cukup sebanyak 2 responden $(3,2 \%)$

5. Pengetahuan ibu hamil tentang cara melakukan akupresur di Puskesmas Margodadi

Hasil penelitian pada ibu hamil tentang cara melakukan akupresur sebagian besar dalam pengetahuan kurang sebanyak 40 responden $(63,5 \%)$ berpengetahuan cukup sebanyak 18 responden $(28,6 \%)$ dan berpengetahuan baik sebanyak 5 responden (7,9\%). Ibu hamil kurang mengetahui tentang cara melakukan akupresur. Akupresur dilakukan dengan Penekanan searah jarum jam sebanyak 30 putaran selama 3-5 menit. Dalam penekanan, sebaiknya jangan terlalu keras dan membuat pasien kesakitan. Penekanan yang benar harus dapat menciptakan sensasi rasa (nyaman, pegal, panas, gatal, perih, kesemutan dan lainnya). Menurut Budiman dan Riyanto (2013) terdapat beberapa faktor yang mempengaruhi pengetahuan, salah satunya adalah pengalaman. Bagaimana cara menyelesaikan permasalahan dari pengalaman sebelumnya yang telah dialami sehingga pengalaman yang didapat bisa dijadikan sebagai pengetahuan apabila medapatkan masalah yang sama. Seluruh responden sesuai dengan teori tersebut, dari jumlah 63 responden semuanya belum pernah melakukan akupresur sehingga responden belum memiliki pengalaman dan pengetahuan tentang cara melakukan akupresur. Menurut penelitian Muthmainah (2010), ada hubungan antara pengetahuan dengan pengalaman. Pengalaman sebagai sumber pengetahuan merupakan suatu cara untuk memperoleh kebenaran pengetahuan dengan cara mengulang kembali pengetahuan yang diperoleh

6. Pengetahuan ibu hamil tentang titik-titik akupresur yang dapat dilakukan pada kehamilan di Puskesmas Margodadi

Hasil penelitian pada ibu hamil tentang titik-titik kehamilan yang dapat dilakukan akupresur sebagian besar responden dalam pengetahuan kurang sebanyak 35 responden $(55,6 \%)$, pengetahuan cukup sebanyak 24 responden $(38,1 \%)$, dan pengetahuan baik sebanyak 4 responden $(6,3 \%)$. Ibu hamil kurang mengetahui tentang tentang titik kehamilan yang dapat dilakukan akupresur diantaranya titik PC 6 (Neiguan) Terletak 2 cun diatas pergelangan tangan, antara tendon m.palmaris longus dan $\mathrm{m}$. flexor carpiradialis. Titik PC 6 atau yang sering disebut dengan titik Neiguan dipercaya dapat mengurangi mual muntah pada ibu hamil (Setyowati, 2018), titik HT7 (Shenmen) titik ini terletak di lipatan pergelangan tangan di bawah jari kelingking di bagian dalam lengan bawah, tepatnya di garis antara jari manis dan kelingking (Ayuningtyas, 2019), Titik GB20 (Fengchi) Gallbladder 20 (GB20) yang juga disebut Feng Chi adalah titik yang disarankan untuk mengatasi sakit kepala, migrain, rabun mata atau kelelahan, kurang energi, serta gejala flu. GB20 terletak di leher (Al-mali, 2018), Titik BL23 (Shenshu) terletak Diantara L II L III, 2 jari lateral dari meridian $\mathrm{Du}$ (bagian Punggung) (Ayuningtyas, 2019). Menurut 
Budiman dan Riyanto (2013) Pendidikan, proses perubahan sikap dan perilaku seseorang atau kelompok dan merupakan usaha mendewasakan manusia melalui upaya pengajaran dan pelatihan. Semakin tinggi pendidikan seseorang maka semakin cepat ia menerima dan memahami suatu informasi sehingga pengetahuan yang dimiliki juga semakin tinggi. Sebagian besar responden sudah sesuai dengan teori yang ada karena sebagian besar responden pada penelitian ini berpendidikan terakhir SMP sebanyak 24 responden $(38,1 \%)$ dan tidak satupun dalam pengetahuan yang baik ataupun cukup. Hal ini dikarenakan tingkat SMP merupakan pendidikan dasar sehingga belum memiliki pendidikan yang tinggi untuk dapat menerima dan memahami suatu informasi yang menyebabkan pengetahuanya kurang. Hasil penelitian Dharmawati dan Nyoman (2016) tingkat pendidikan memiliki hubungan dengan tingkat pengetahuan seseorang, karena tidak dapat dipungkiri bahwa semakin tinggi pendidikan seseorang semakin tinggi pula mereka menerima informasi yang pada akhirnya semakin banyak juga pengetahuan yang dimiliki. Begitupun sebaliknya, jika seseorang tingkat pengetahuanya rendah tentunya akan mengahambat perkembangan sikap seseorang dalam menerima informasi.

\section{SIMPULAN}

Secara umum hasil penelitian yang dilakukan pada 63 ibu hamil diwilayah kerja Puskesmas
Margodadi, sebagian besar ibu hamil dalam pengetahuan kurang sebanyak 51 responden $(81,0 \%)$. Secara khusus hasil penelitian ini menunjukan bahwa pengetahuan ibu tentang pengertian akupresur dalam pengetahuan kurang sebanyak 51 responden $(81,0 \%)$, manfaat akupresur dalam pengetahuan kurang sebanyak 49 responden $(77,8 \%)$, kontraindikasi akupresur dalam pengetahuan kurang sebanyak 52 responden $(82,5 \%)$, cara melakukan akupresur dalam pengetahuan kurang sebanyak 40 responden $(63,5 \%)$, dan titik-tik akupresur yang dapat dilakukan pada kehamilan dalam pengetahuan kurang sebanyak 35 responden $(55,6 \%)$.

\section{UCAPAN TERIMA KASIH}

Peneliti sampaikan ucapan terimakasih kepada Universitas Ngudi Waluyo, ibu hamil yang bersedia menjadi responden dalam penelitian, dan seluruh pihak yang turut mendukung penelitian ini sehingga dapat berjalan dengan lancar.

\section{DAFTAR PUSTAKA}

Akbarzadeh, dkk. (2015). Comparison of the effects of doula supportive care and acupressure at the BL32 point on the mother's anxiety level and delivery outcome. Irian Journal of Nursing and Midwifery Research. Vol 20 No 2.

Al'amali Mayla Khayra, Ario Imandiri, Sukardiman. (2018). Terapi Akupresur Serta Herbal Kencur Pada Kasus Migrain. Journal of Vocational Health Studies. 
Vol 02. Hal 80- 85. Diakses 10 Oktober 2020

Ayuningtyas, Ika Fitria. (2019). Kebidanan Komplementer Terapi Komplementer Dalam Kebidanan. Yogyakarta: Pustaka Baru Press

Budiman \& Riyanto A. (2013). Kapita Selekta Kuisioner Pengetahuan Dan Sikap Dalam Penelitian Kesehatan. Jakarta : Salemba Medika

Carter, W. (2011). Disaster Manegement : A Disaster Manager's Handbook. Manila : ADB; 1-204

Dharmawati I G A Ayu dan I Nyoman Wirata, (2016). Hubungan Tingkat Pendidikan, Umur, Dan Masa Kerja Dengan Tingkat Pengetahuan Kesehatan Gigi Dan Mulut Pada Guru Penjaskes Sd Di Kecamatan Tampak Siring Gianyar. Jurnal Kesehatan Gigi. Vol 4 No 1

Hartatik, (2012). Tingkat Pengetahuan Ibu Hamil Tentang Inisiasi Menyusu Dini di BPS Dyah Sumarmo Boyolali.

Hartono, R. I. W. (2012). Akupresur untuk berbagai penyakit. Yogyakarta: Rapha Publishing

Irianti, Bayu. dkk. (2013). Asuhan Kehamilan Berdasarkan Bukti, Jakarta : CV Sagung Seto

Kementrian Kesehatan RI. (2015). Panduan Akupresur Mandiri
Bagi Pekerja ditempat Kerja.

Jakarta.

Kesehatan

Kementrian RI

Kundaryanti Rini, dkk. (2016). Hubungan Antara Pendidikan

Dan Sumber Informasi Dengan Tingkat Pengetahuan Ibu Tentang Post Partum Blues Di Rb Ratna Komala Bekasi Jawa Barat Tahun 2013. ISSN 2356. Vol 2 No 1. Febriari 2016.

Latifah Ulfatul, Istiqomah Dwi, Mutiarawati. (2020).

Peningkatan Pengetahuan Tentang Akupresur Untuk Mengurangi Nyeri Haid Pada Remaja Putri. Jurnal Abdimas $P H B$ Vol 3 No 2 Juni . diakses 10 Oktober 2020

Meiri dan Kibas. (2018). Pengaruh Akupresur Pada Titik Nei Guan, Zu Sanli Dan Gongsun Terhadap Pengurangan Mual Muntah Pada Ibu Hamil Trimester I Di PMB Afah Fahmi A.Md.Keb. Jurnal Medika Respati. Vol 13 No 3

Muthmainnah, F. (2010). FaktorFaktor yang Berhubungan dengan Pengetahuan Ibu dalam Memberikan Makanan Pendamping Air Susu Ibu di Puskesmas Pamulang Tahun 2010. Skripsi UIN Syarif Hidayatullah Jakarta

Neri Isabella, Rafaelle Bruni, Giulia, et. (2015). Acupressure On Self-Reported Sleep Quality During Pregnancy. Journal of Acupunture and Meridian Studies. 9(1):11-15. Diakses 10 Oktober 2020 
Pangesti, A. (2012). Gambaran tingkat pengetahuan dan aplikasi kesiapsagaan bencana pada mahasiswa Fakultas Ilmu Keperawatan Universitas Indonesia Tahun 2012. Universitas Indonesia

Prawirohardjo, Sarwono. (2014). Ilmu Kebidanan Sarwono Prawirohardjo. Jakarta: PT. Bina Pustaka Sarwono Prawirohardjo

Setyowati. (2018). Akupresur Untuk Kesehatan Wanita Berbasis Hasil Penelitian. Magelang : Unimma Press

Sukeksi Niken Tri, Gita Kostania, Emy Suryani. (2018). Pengaruh Teknik Akupresur Terhadap Nyeri Punggung Pada Ibu Hamil di Wilayah Puskesmas Jogonalan I Klaten. Jurnal Kebidanan dan Kesehatan Tradisonal. Vol 3 No 1. Halaman 1-56. Diakses 10 Oktober 2020

Sunetra.(2004). Hidup Sehat Dengan Akupresure. $\quad$ Surabaya: Paramita.

Tiran, Denise. (2008). Mual dan Muntah Kehamilan : Seri Ausaan Kebidanan (Nausea and vomiting in Pregnancy: An Integrated Approach to Care. Jakarta. EG

Yanti Damai. (2017). Konsep Dasar Asuhan Kehamilan. Bandung: PT Refika

Aditama. 